\title{
The Effect of Green Human Resources Management on Sustainability Business Companies \\ (Case Study on Employee Claim Department PT. Prudential Life Assurance)
}

\author{
Erfina Tri Wulandari and Lenny Christina Nawangsari
}

\section{ABSTRACT}

\begin{abstract}
The purpose of this research is to measure the impact of Green Human Resources Management towards business sustainability at PT. Prudential Life Assurance. The type of this research is a quantitative research. Analysis of the data used in this study using SEM PLS version 3.2.7. About 94 respondents from Claim Department at PT. Prudential Life Assurance participated in this research. Based on direct impact shows that Green Recruitment, Green Training, Green Compensation and Rewards have brought a positive and significant impact towards business sustainability, however, there is no significant impact for Green Performance Appraisal. Simultaneously, Green Human Resources Management has a positive and significant impact to Business Sustainability at PT. Prudential Life Assurance.
\end{abstract}

Keywords: Green Human Resources, Green Recruitment, Green Training, Green Performance Appraisal, Green Compensation and Rewards dan Sustainability Business.

\section{INTRODUCTION}

Environmental problems and how to protect them are important issues around the world. One of them is pollution from the company's operational activities. All parties, especially internal parties, need to pay attention to the environment in the workplace. So, one way for companies to solve this problem is by implementing green offices and green corporations.

The application is of course with company policies in terms of managing human resources in a sustainable manner, namely the Green Human Resources Management (GHRM). PT. Prudential is currently starting to pay attention to and implement GHRM. This practice is implemented in order to support the idea of a green office and green corporate, because the company realizes that pro-environmental behavior at the individual level is needed in order to create sustainable company performance.

To measure the performance of a company in a "holistic" manner by taking into account economic work measures in the form of profit, social awareness measures, and environmental preservation, the concept used is the triple bottom line concept.

In the concept of profit, it can be seen from how the company gets the profit which is reflected in the premium income report of PT. Prudential Life Assurance which has been audited.

\author{
Submitted : February 8, 2021 \\ Published : February 26, 2021 \\ ISSN: 2507-1076 \\ DOI: $10.24018 /$ ejbmr.2021.6.1.745 \\ Erfina Tri Wulandari \\ Magister Management, Mercu Buana \\ University, Jakarta, Indonesia \\ (e-mail: finawarso@gmail.com) \\ Lenny Christina Nawangsari* \\ Magister Management, Mercu Buana \\ University, Jakarta, Indonesia \\ (e-mail: lenny.christina ${ }^{\circledR}$ mercubuana.ac.id)
}

*Corresponding Author

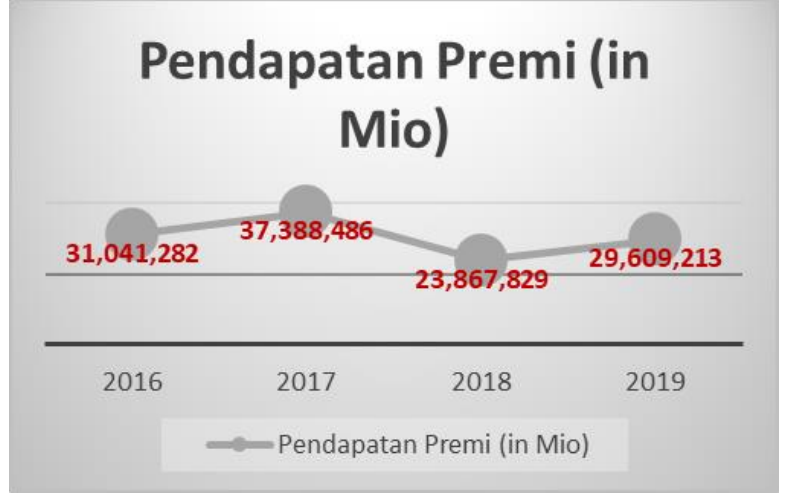

Fig. 1. Premium Income Report of PT. Prudential Life Assurance.

The planet concept carried out by PLA can be seen from the CSR program it is running. It has just been run since 2012 and the selection of volunteers is only at PT. The central Prudential Life Assurance, Jakarta, makes this concept not yet comprehensive and maximally implemented [1].

In implementing the concept of people in order to increase the concern of all employees in creating a beautiful work environment, it has not been widely implemented. Employees do not understand because there is little training and development that focuses on the environment at Prudential Life Assurance.

The author has also conducted a pre-survey to 24 people to identify problems that exist in PT. Prudential Life Assurance. It is known from the results of the pre-survey that the 
variables in GHRM, namely green recruitment, green training, green performance and appraisal as well as green compensation and rewards have not been maximally implemented.

In addition, in previous research it was found that green training did not affect a company's business sustainability [2].

So that underlies the author to conduct research that aims to determine and analyze how the actual effect of GHRM in the sustainability business of PT. Prudential Life Assurance and made a study entitled "The Effect of Green Human Resources Management on the Company's Sustainability Business (Case Study on Employees of the Claim Department of PT. Prudential Life Assurance)".

\section{LITERATURE REVIEW AND HYPOTHESIS DEVELOPMENT}

\section{A. Green Recruitment}

Green recruitment is a process where companies attract and recruit candidates with the knowledge, skills, attitudes, and behaviors that are in accordance with the environmental management system of an organization [3]. At present, attracting talented, creative and innovative employees is indispensable for organizations, so increasing the potential for recruitment and recruitment of quality staff is a big challenge [4]. There are several factors that are used as indicators in green recruitment, namely: 1) Green awareness of candidates 2) Branding of employers 3) Employees based on green criteria.

\section{B. Green Training}

Green training according to [5] is a practice that focuses on developing skills, knowledge and attitudes of employees who are environmentally friendly which refers to a system of environmental protection activities and paying attention to environmental problems in achieving the company's environmental goals. The training carried out by the company is expected to increase the awareness, knowledge and skills of employees in understanding more about the importance of protecting the environment and making them sensitive to the process of controlling and preventing environmental destruction.

\section{Green Compensation and Rewards}

Green Compensation and Rewards are potential tools that companies use as both financial and non-financial reward systems that aim to attract, retain and motivate employees to contribute to the company's environmental goals [6].

\section{Green Performance and Appraisal}

Green performance and appraisal or assessment and green performance management according to previous research is where green performance management creates green performance indicators that contain a set of green criteria for all employees in performance appraisals, which include environmental incidents, responsibility and reduction of carbon emissions, as well as how communicate environmental concerns and policies [7].

\section{E. Green Human Resources Management}

Green human resources management (GHRM) defined by previous research is the implementation of HR management policies and practices for sustainable resource use in business organizations and promoting environmental sustainability [8]. According to another previous research. GHRM is defined as the process of making employees greener by using "green" human resource policies and practices [9].

\section{F. Sustainability Business}

A sustainability business is a business that uses a triple bottom line (profit, people and planet), where a business will carry out its business model by managing not only finances but also seeing how the social impact and impact on the environment [10].

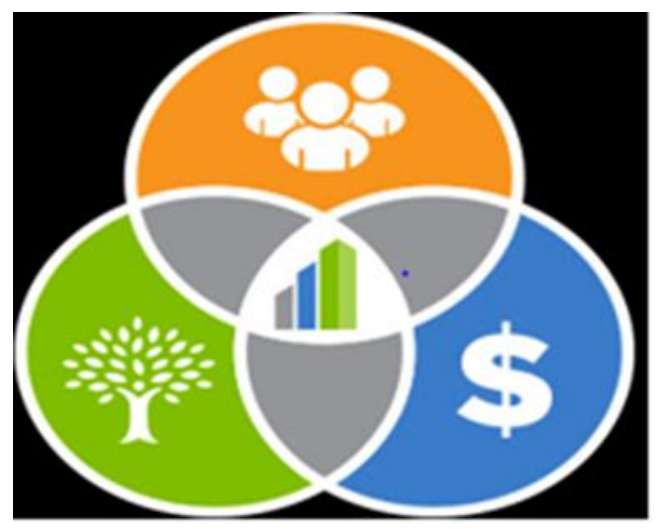

Fig. 2. Triple Bottom Line.

In addition, sustainable businesses expand their products and services through broad and deep interests in economic, social, and environmental corridors. The view which states that the use of the dimensions of sustainable development into a narrow business must be removed with a broader vision and long-term business insight is also promising [11].

\section{G. Previous Research}

Based on research in previous research, it was found that there was a significant relationship between green recruitment and green training with the company's green performance [12]. Another research found that GHRM has a positive effect in recruiting new employees who care about green business practices [13]. And research conducted by another research where it was found that GHRM has a significant effect on the company's sustainable business. However, that research found that from the results of his research green training did not affect the sustainability of the company [2].

\section{H. Conceptual Framework}

From the phenomena, research objects and previous research that have been stated, the theoretical framework that can be presented is as follows: 


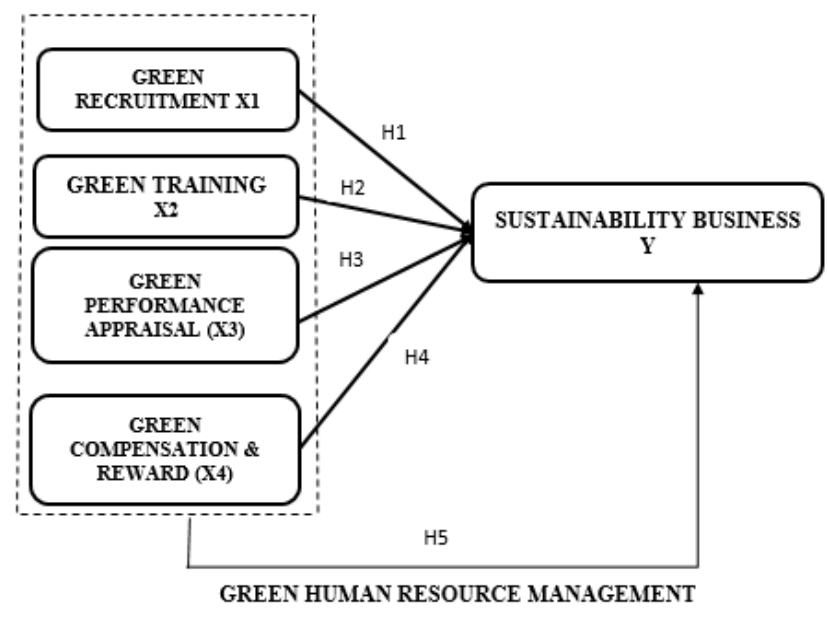

Fig. 3. Conceptual Framework.

\section{Hypothesis}

Based on the theoretical framework described above, the hypothesis formulated by the authors in this study can be described as follows:

Hypothesis 1 (H1): Green Recruitment has a positive and significant effect on the Sustainability Business of PT. Prudential Life Assurance

Hypothesis 2 (H2): Green Training has a positive and significant effect on the Sustainability Business of PT. Prudential Life Assurance.

Hypothesis 3 (H3): Green Performance Appraisal has a positive and significant effect on the Sustainability Business of PT. Prudential Life Assurance.

Hypothesis 4 (H4): Green Compensation and Reward has a positive and significant effect on the Sustainability Business of PT. Prudential Life Assurance.

Hypothesis 5 (H5): Green Human Resource and Management simultaneously has a positive and significant effect on the Sustainability Business of PT. Prudential Life Assurance.

\section{RESEARCH METHODOLOGY}

The method of analysis in this study uses quantitative methods through the causality approach. The exogenous variables in this study are green recruitment, green training, green performance appraisal and green compensation and reward. Meanwhile, the endogenous variable in this study is business sustainability. The estimation scale used is the Likert scale. The population of this study were employees at the claim department of PT. Prudential Life Assurance, with the total number of employees at claim department is 123 employees, while the sample is 94 respondents (using Slovin, error tolerance of 5\%). Methods of data analysis using Structural Equation Modeling-Partial Least Square with the help of the SmartPLS 3.0 program to test the hypothesis.

\section{RESEARCH RESULTS AND DISCUSSION}

\section{A. Respondent Characteristics}

In accordance with the characteristics of 94 respondents who are employees of claim department at PT. Prudential Life Assurance, it is known that the majority of employees are women $(70.2 \%)$, age $25-35$ years $(73.4 \%)$, undergraduate education $(98.9 \%)$ and with a work period of 5-10 years (78, $7 \%$ ). This illustrates that employees claim department at PT. Prudential Life Assurance is a woman who has worked for a long time at PT. Prudential Life Assurance, so that you already know how the environmental performance is running in the company.

\section{B. Outer Model Measurement}

Based on the convergent validity test, it is known that all indicators in this study have a loading factor value $>0.5$. So that, from testing, no indicators are removed from the model and all research indicators are declared valid.

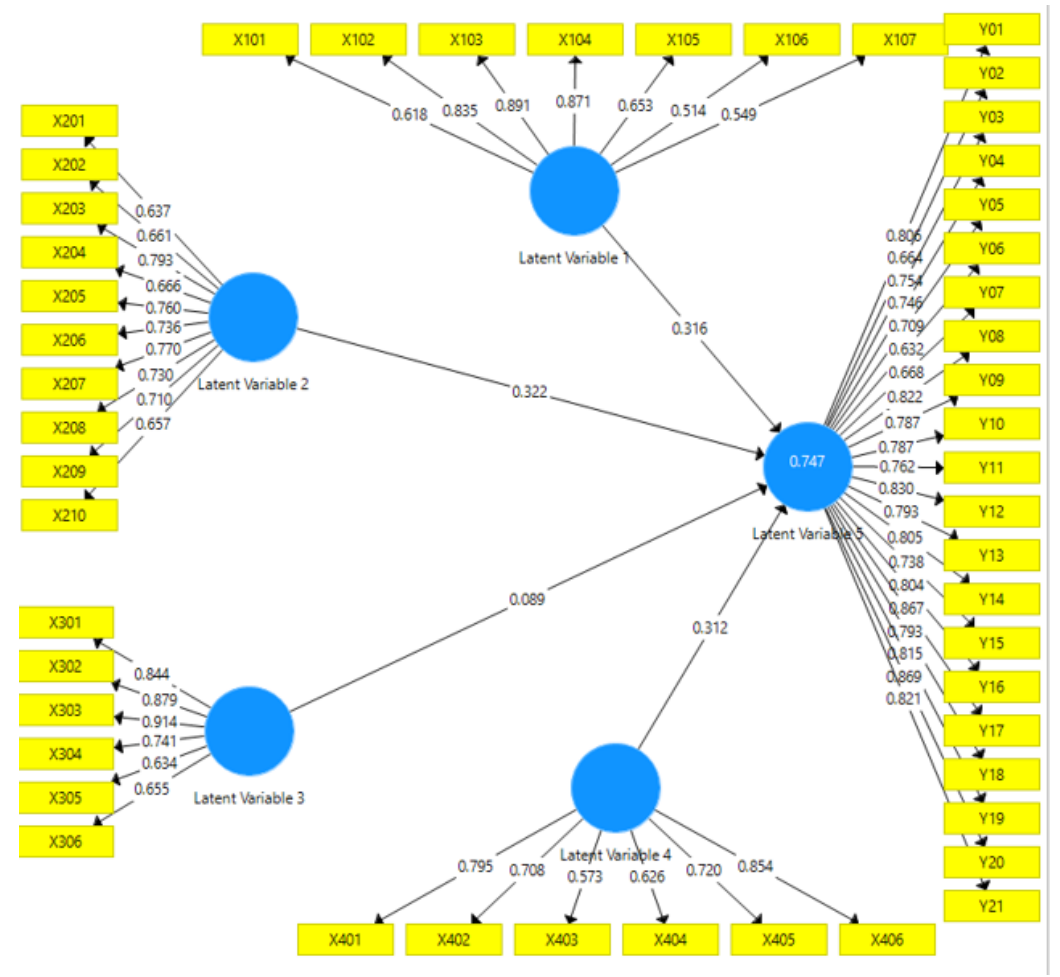

Fig. 4. Outer Model. 
Based on the reliability test, it is known that the Cronbach's Coefficient Alpha and Composite Reliability values of all variables are $>0.60$, even close to 1 , meaning that all variables have met high reliability standards.

TABLE I: RELIABILITY TEST RESULTS

\begin{tabular}{cccc}
\hline \multicolumn{4}{c}{ TABLE I: RELIABILITY TEST RESULTS } \\
\hline Labels & Variable & $\begin{array}{c}\text { Cronbach's } \\
\text { Coefficient }\end{array}$ & $\begin{array}{c}\text { Composite } \\
\text { Reliability }\end{array}$ \\
\hline X1 & Green Recruitment & 0,831 & 0,839 \\
X2 & Green Training & 0,892 & 0,894 \\
X3 & $\begin{array}{c}\text { Green Performance } \\
\text { Appraisal }\end{array}$ & 0,870 & 0,868 \\
X4 & $\begin{array}{c}\text { Green Compensation } \\
\text { and Rewards }\end{array}$ & 0,808 & 0,823 \\
& Sustainability & 0,967 & 0,969 \\
\hline & Business & & \\
\hline
\end{tabular}

\section{R Square test, Predictive Relevance (Q2), Goodness of} Fit Index (GoF), and F Count

Based on the results of the R Square test, it can be seen that the R Square Adjusted for the sustainability business variable is 0.736 . This means that the variables of green recruitment, green training, green performance appraisal and green compensation and rewards simultaneously influence $73.6 \%$ of business sustainability, while $26.4 \%$ are influenced by other variables outside of this study. Then based on the Q2 test it is known that the value of $\mathrm{Q} 2=0.736>0$, so this model has good predictive relevance. Based on the results of the GoF calculation, it is known that Gof $=0.637>0,38$. This means that the combined performance between the measurement model (outer model) and the structural model (inner model) is quite large and good. Based on the results of the calculation of F Count, it is known that F count> F Table, namely $63,448>2.31$. This means that simultaneously exogenous variables have a significant effect on endogenous variables.

\section{Hypothesis testing}

The results of the hypothesis testing in this study can be seen in the table presented below.

TABLE II: HYPOTHESIS TEST RESULTS

\begin{tabular}{|c|c|c|c|c|}
\hline Hypothesis & Variable & $\begin{array}{c}\text { T-Statistic } \\
\text { (O STDEV) }\end{array}$ & $\begin{array}{c}\text { P- } \\
\text { Values }\end{array}$ & Results \\
\hline $\mathrm{X} 1-\mathrm{Y}$ & $\begin{array}{c}\text { Green Recruitment } \\
->\text { Sustainability } \\
\text { Business }\end{array}$ & 5,034 & 0,000 & Accepted \\
\hline $\mathrm{X} 2-\mathrm{Y}$ & $\begin{array}{c}\text { Green Training -> } \\
\text { Sustainability } \\
\text { Business } \\
\text { Green }\end{array}$ & 3,073 & 0,002 & Accepted \\
\hline $\mathrm{X} 3-\mathrm{Y}$ & $\begin{array}{c}\text { Performance \& } \\
\text { Appraisal -> } \\
\text { Sustainability } \\
\text { Business }\end{array}$ & 0,911 & 0,363 & Rejected \\
\hline $\mathrm{X} 4-\mathrm{Y}$ & $\begin{array}{c}\text { Green } \\
\text { Compensation \& } \\
\text { Rewards -> } \\
\text { Sustainability } \\
\text { Business }\end{array}$ & 4,278 & 0,000 & Accepted \\
\hline
\end{tabular}

Based on the results of the hypothesis test presented above, it is said that green recruitment, green training and green compensation and rewards have a positive and significant effect on business sustainability, while green performance appraisal is known to have no significant effect on business sustainability

\section{E. Discussion}

Based on the hypothesis testing in this study, it shows that partially green recruitment has a positive and significant effect on business sustainability. The results of this study are in line with the research of previous research who found that green recruitment has a positive effect on business sustainability because currently green recruitment and selection are important components of Green HRM practice [14]. This needs to be done so that the company gets candidates who are suitable for the company in carrying out green performance so that business sustainability occurs.

Based on the hypothesis testing in this study, it shows that partially green training has a positive and significant effect on business sustainability. The results of this study are in line with previous research which revealed that comprehensive green training can increase knowledge of green performance [5]. Because the training can motivate employees to learn skills and how to protect the environment by implementing green performance in accordance with the company's business.

Based on the hypothesis testing in this study, it shows that partially green performance and appraisal have no significant effect on business sustainability. This is not in accordance with this research, which is not in line with previous research from previous research which from the results of their research found that green performance appraisal has a significant effect on business sustainability [15]. So, the results of this study are the same as the conditions that occur in companies where the company has not included green performance as one of the assessment indicators, so that employees have low motivation to implement green performance in their work.

Based on the hypothesis test in this study, it shows that partially green compensation and rewards have a positive and significant effect on business sustainability. The results of this study are in line with previous research which explains that promotions and rewards in the field of environmental care have an effect on employee behavior in working optimally and being sensitive to the environment [6]. Based on the research above, it can be interpreted that green compensation and rewards in the company are very useful to provide motivation to increase their competence at work. In addition, there is an appreciation for ideas or input regarding how green performance is implemented in a work environment, which will trigger many ideas from every employee. In addition, awards can also be given to employees who carry out green performance in their work to motivate other employees to be able to implement green performance.

Based on the hypothesis testing in this study, it shows that GHRM (green recruitment, green training, green performance appraisal, green compensation and rewards) simultaneously has a significant effect on business sustainability. The results of this study are in line with previous research from previous research whose research results show that green human resources management has a positive effect on the company's business sustainability [15]. Based on the results of this study, companies can further 
optimize GHRM simultaneously in running their companies in order to achieve business sustainability in the future.

\section{CONCLUSIONS}

From the final results and discussion conducted by the author, conclusions can be drawn based on proving the hypothesis built in this study, such as:

1) Green recruitment has a positive and significant effect on business sustainability.

2) Green training has a positive and significant effect on business sustainability.

3) Green performance and appraisal have no significant effect on business sustainability.

4) green compensation and rewards have a positive and significant effect on business sustainability.

5) Green human resources management simultaneously affects business sustainability.

After drawing conclusions from the results of the data processing, there are several suggestions that can be taken into consideration by PT. Prudential Life Assurance and further researchers, namely as follows:

1) There needs to be attention from the company to its employees who have done green performance well or employees who give ideas to be rewarded and compensated, so that employee motivation in implementing the green performance and other employees will continue to increase.

2) The company improves its assessment by including green performance as one of the indicators of employee performance appraisals, so that it can motivate and spur employees to improve their green performance in the company.

3) The company is advised to increase the provision of evenly distributed green training to all employees regularly and periodically so that each line of employees can find out about how green performance in the company is run.

4) In addition, companies are also advised to be able to carry out, improve and maintain green recruitment, green training, green performance appraisal as well as maximum green compensation and rewards in order to achieve business sustainability in the future.

5) Based on the results of this study, the authors suggest that further research can discuss other variables of green human resources management that affect business sustainability. In addition, further research is expected that the respondents studied not only come from the claim division but are able to conduct thorough research, from the sales force to operational levels.

\section{REFERENCES}

[1] Fairuz, dkk. 2018. Corporate Social Responsibility in PT. Prudential Life Assurance. Jurnal UNPAD, Vol: 5, No 3.

[2] Iqbal, Javeed. 2016. The Effect of Green HRM Practices on Sustainability: Evidence from Manufacturing Companies in Pakistan. Pakistan Journal of Social Sciences (PJSS) Vol. 36, No. 1 (2016), pp. 177-188.

[3] Ullah, dkk. 2017. Greening Human Resource Management: A Review Policies and Practices. Advance Science Letters. Volume 23, No 9.

[4] Renwick, dkk. 2013. Green Human Resource Management: A Review and Research Agenda. International Journal of Management Reviews.
[5] Jabbour, Jabbour. 2015. Green Human Resource Management and Green Supply Chain Management: Linking two emerging agendas. Journal of Cleaner Production. 112.

[6] Saeed, dkk. 2018. Promoting employee's proenvironmental behavior through green human resource management practices. ERP Environment and John Wiley \& Sons Ltd.

[7] Delmonico, dkk. 2018. Unveiling barriers to sustainable public procurement in emerging economies: evidence from a leading sustainable supply chain initiative in Latin America. Resources, Conservation and Recycling, 134, 70-79.

[8] Rawashdeh. 2018. The Impact of Green Human Resource Management on Organizational Environmental Performance in Jordanian health service Organizations. Management Science Letter 8. Hal. 1049-1058.

[9] Opatha, Arulrajah. 2015. Green Human Resource Management: Simplified General Reflections. International Business Research hal. 101-112.

[10] Nugraha, dkk. 2015. Implementasi Kegiatan Corporate Social Responsibility "Go Green Economic" Berbasiskan Kearifan Lokal. Jurnal Komunikasi. Vol. 7, No. 2. Hal 118-128.

[11] Bombiak Kluska. 2018. Green Human Resource Management (GHRM) as a Tool for the Sustainable Development of Enterprises: Polish Young Company Experience. MDPI.

[12] Sinaga, Nawangsari. 2019. The Effect of Green Recruitment, Green Training on Employee Performance in PT TRU Using Organization Citizenship for Environment as Mediation Variable. Dinasti International Journal of Management Science.

[13] Bangwal, Tiwari. 2015. Green HRM-A way to greening the environment. IOSR Journal of Business and Management (IOSR-JBM) Vol 17, Issue 12. Ver I.

[14] Nejati, dkk. 2019. Green Human Resource Management. International Journal of Manpower.

[15] Purnama, Nawangsari. 2019. Pengaruh Green Human Resource Management Terhadap Sustainability Business: Pendekatan Konsep. Seminar Nasional Peningkatan Mutu Perguruan Tinggi, Universitas Mercu Buana Jakarta. 